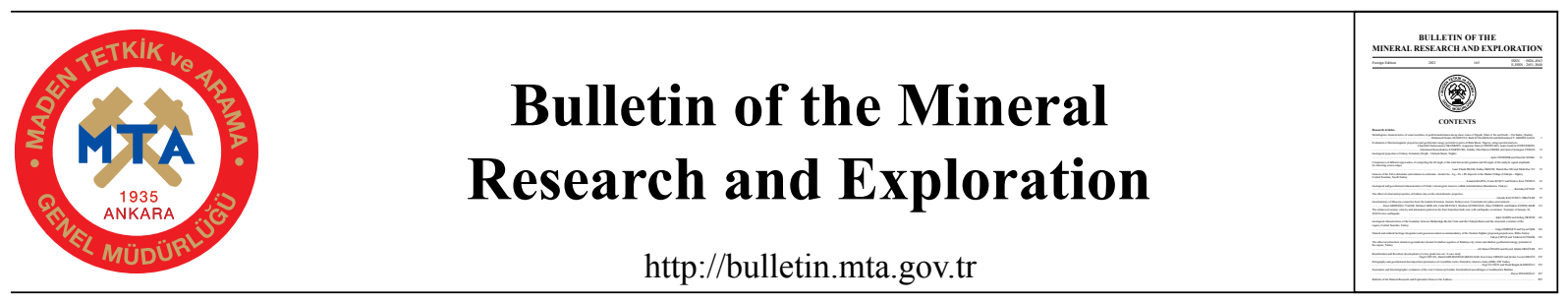

\title{
Metallogenic characteristics of some localities of gold mineralization along shear zones of Elgaab, Dum el Tor and Sodri - Um Bader, (Sudan)
}

\author{
Mohamed Osman ELGIZOULI ${ }^{\mathrm{a}^{*} \mathbb{D}}$, Badr El Din KHALIL ${ }^{\mathrm{b}} \mathbb{\mathfrak { D }}$ and Mohammed Y. ABEDELGALIL $^{\mathrm{b}} \mathbb{( D}$ \\ ${ }^{\mathrm{a}}$ Geological Research Authority of the Sudan, Khartoum, Sudan \\ ${ }^{\mathrm{b}}$ Al Nileen University, Faculty of Petroleum and Minerals, Khartoum, Sudan
}

Research Article

Keywords:

Shear, Related, Gold, Pan - African Orogeny, Metallogeny, Sudan.

\begin{abstract}
Study area is located in the eastern sector of Saharan Meta - Craton that includes the western part of Bayuda Terrane and extend southwest to Sodri - Um Badir shear zones. The sector is dominated by metasediments, metavolcanic - sedimentary series represented by chlorite - schist, quartzite, calc silicate, and marble. Low - grade metamorphic arc - related volcano - sedimentary sequence occurs as thin narrow bands and subjected to tectono - thermal events of Pan - African orogeny during the Late - Proterozoic era ( 900 - $550 \mathrm{Ma}$ ). All these rock sequences have been intruded by syn to Late Orogenic Granitoids and post - orogenic ring - shaped complex and felsic dykes. The intrusions are thought to be the source of hydrothermal fluids that caused the precipitation of gold. Similar characteristics of geological features and tectonic settings support the possibility of the extension of gold mineralization between shear zones. The comparison between the three gold mineralizations reveals variations in minerals assemblages, pathfinders and gold grade. The result of this study defines a new metallogenic province in the west of the River Nile, which occupies a very large area covered by Phanerozoic sediments. Numerous mineral deposits of economic potentiality have been targeted along the shear zones and related fractures and faults. Among those potential deposits, five of them have been chosen as targets for future gold exploration and evaluation.
\end{abstract}

\section{Introduction}

The study area is located in the eastern sector of Saharan meta craton, which is bounded by Uweinat Salima tectonic belt in northwest Rahib ophiolite Belt in the southwest, and the southwestern boundary is the NE trending Wadi Hawar uplift. Central Africa Fault Zone with deep NE - SW - striking faults extended through the southern side and the western margin of Bayuda desert is bounded eastern side of the study area (Figure 1). The area is relatively flat and cover by thick Phanerozoic sediments. Field observations, geological mapping, and geochemical investigations suggest that study area, dominated by low - grade meta - volcano - sedimentary sequences, has similar litho - tectonic features with North Kurdofan considered by Rahman and Elmahi, (2006) as a possible west continuation of the Upper Proterozoic Pan African Arabian Nubian Shield. The general NE - SW striking of the low grade Pan - African rocks sequences was parallel to the dominant strike directions all over the Arabian Nubian shield. Gold mineralizations in Elgaab, Hamadi gold mine (Dum el Tor) and Gammama area of Sodri Um Bader shear zones reveal similar characteristics geological, structural features and tectonic settings.

Citation Info: Elgizouli, M.O., Khalil, B.E.D., Abedelgalil, M.Y. 2021. Metallogenic characteristics of some localities of gold mineralization along shear zones of Elgaab, Dum el Tor and Sodri - Um Bader, (Sudan). Bulletin of the Mineral Research and Exploration 165, $1-12$. https://doi.org/10.19111/bulletinofmre.695138

*Corresponding author: Mohamed Osman ELGIZOULI, mohosmelg111@gmail.com 


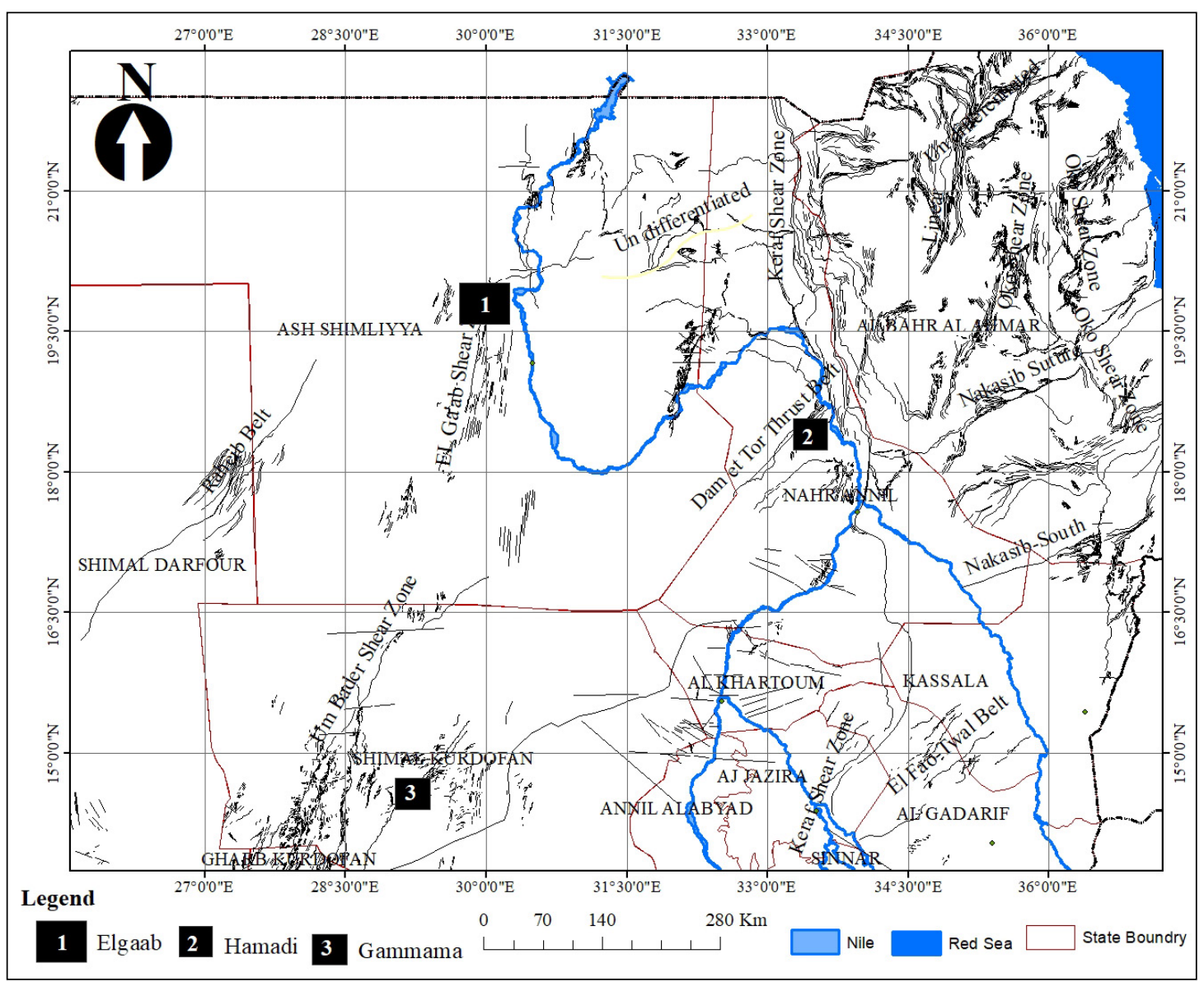

Figure 1- Location map of areas of study.

These characteristics support the possibility of the continuation of gold mineralization between the shear zones.

\subsection{Applied Method}

A total of 246 samples (25 chips of quartz and rocks, 31 soil, and 190 trenches samples) have been collected and analyzed using X - Ray fluorescence (XRF) method and Atomic Absorption Spectrometry (AAS) XRF analytical method: $10 \mathrm{~g}$ of powder sample mix by wax as binder press by pressing machine to make pallets, then read by XRF instrument, calibrated by panalytical stander for all elements (from $\mathrm{Be}$ to $\mathrm{U}$ ). The determined elements depend on the wave length of the elements. AAS, used for analysis of basic elements $\mathrm{Co}, \mathrm{Ni}, \mathrm{Zn}, \mathrm{Fe}$ etc.

$0.5 \mathrm{~g}$ of powder sample adds to mixture of acid hydrofluoric, per chloric and nitric $(10 \mathrm{ml}, 5 \mathrm{ml}$ and $2 \mathrm{ml}$ respectively). Dry in hot plate after add $10 \mathrm{ml}$ of $\mathrm{HCl}$ $50 \%$ then transfer the solution into $50 \mathrm{ml}$ volumetric flask then read it by AAS after calibrated by series of stander solutions. The artisanal gold mining mega-pits and trenches in Elgaab area have helped substantial investigations of the subsurface geology, besides the description of the shapes, features and geometry of the ore body, lithological horizon bearing mineralization since there are no boreholes and geophysical survey conducted in the area. The main aim of the study is to define spreading of the gold mineralization along shear zones beneath thick cover of Phanerozoic sediments. As a result of the study, based on the geological, geochemical and structural features, possible new metallogenic province is defined in the west part of River Nile. In the process, geological, geochemical and structural studies were carried out in the three shear zones.

\section{Geological Setting}

\subsection{Lithology}

Metasediments, metavolcano - sedimentary series represented by chlorite - schist, quartzite, calc 
- silicate, and marble are dominantly outcropped in the study area. Low - grade metamorphic arc - related volcano - sedimentary sequence occurs as thin narrow bands and subjected to tectono - thermal events of PanAfrican orogeny during Late - Proterozoic era (900 $550 \mathrm{Ma}$ ), resulted in low - grade green - schist to lower amphibolite facies, with local high - grade gneiss inlier. All these rock sequences have been intruded by syn to late orogenic granitoids mainly diorite and post - orogenic ring - shaped complex and felsic dykes. The basement rocks of Northern Kurdofan consist of high - grade and low - grade metamorphic assemblage exposed in the foreland of the Arabian - Nubian Shield in the western Nile. Those assemblages are intruded by syn - orogenic granite and post - orogenic granite and dykes. Shear zone related fractures were intruded by intermediate to acidic composition dykes such as quartz porphyry, dacite and trachyte (Figure 2).

\subsection{Geotectonic and Local Structures}

The continuation of Delgo - Atmur suture in the eastern Nile, were represented by NNE striking Elgaab shear zone, which possible reaches Sodri Um Badir shear zones in North Kurdofan. Dum el Tor Shear zone which represents the western branch of the Red Sea - Oko shear zone of Nakasib Suture into East Bayuda Desert, and possibly continues westwards. The rifting between East Sahara / Halfa and Bayuda / Kurmut terranes had began before $750 \mathrm{Ma}$ and might have started as early as $830 \mathrm{Ma}$ (Kuster and Liegeois, 2001). Then followed by sea floor spreading and ocean

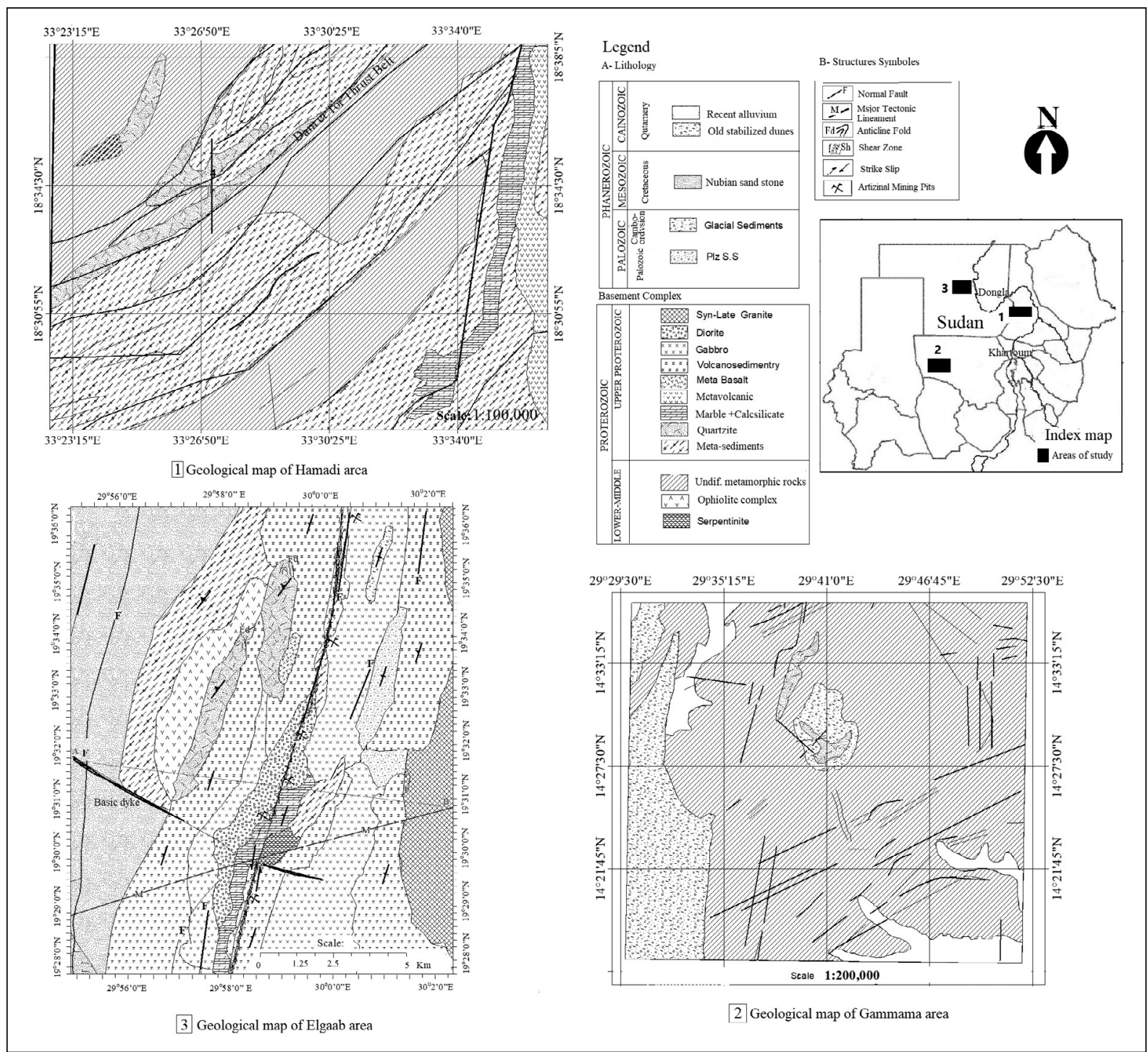

Figure 2- Geological map of the areas of study. 
basin formation. Suturing of the terranes was initiated at around $720 \mathrm{Ma}$, and it was probably completed by $700 \mathrm{Ma}$ (Stern et al., 1994). The Basin closure driven by $\mathrm{N}-\mathrm{S}$ shortening and collision between Halfa and Bayuda / Kurmut terranes started at southeastern part of the Halfa terrane probably around $750 \mathrm{Ma}$ (Abdelsalam et al.,1995).

The obduction of Atmur-Delgo ophiolite took place $\sim 702 \mathrm{Ma}$ (Harms et al., 1994), and the peak metamorphism were accepted to occur coeval. Collision between Bayuda / Kurmut and Halfa terranes was associated with progressive deformation, granitoid intrusions and metamorphism that continued until $650 \mathrm{Ma}$. These granitoid intrusions are accepted as the source of hydrothermal fluids that precipitate gold. Data from Jebel Rahib ophiolite within Rahib belt indicates that an ocean was present at $\sim 740 \mathrm{Ma}$ until its closure at $\sim 707 \mathrm{Ma}$ (Harms et al., 1994). Multi - phase deformation has affected the basement rocks in the study area. A pair of anticline - syncline overturn fold system with NE - SW trending axial plane is recognized in the mapped area. The NNE normal faults also deformed the rocks in the study area. Other set of E - W striking fault represent by second order drainage pattern, cutting lithological units and displaced the NE - SW trending lineament (Figure 3). The study area is traversed by NE striking major shear zone and extends several hundred kilometers parallel to Dam El Tor shear zone, suggested earlier as western continuation of Sodri - Um Badir shear zone of Northern Kurdofan (Rahman and Elmahi, 2006). The central part of the shear zone in the area characterized by the present of quartz veins, which are formed in the highly sheared acidic, intermediate and basic meta - volcanic and meta - sediment in Hamadi gold mine area.

More than five phases of deformation have affected the Hamadi gold mine in the East Bayuda area. The first phase is a bedding - parallel schistosity.

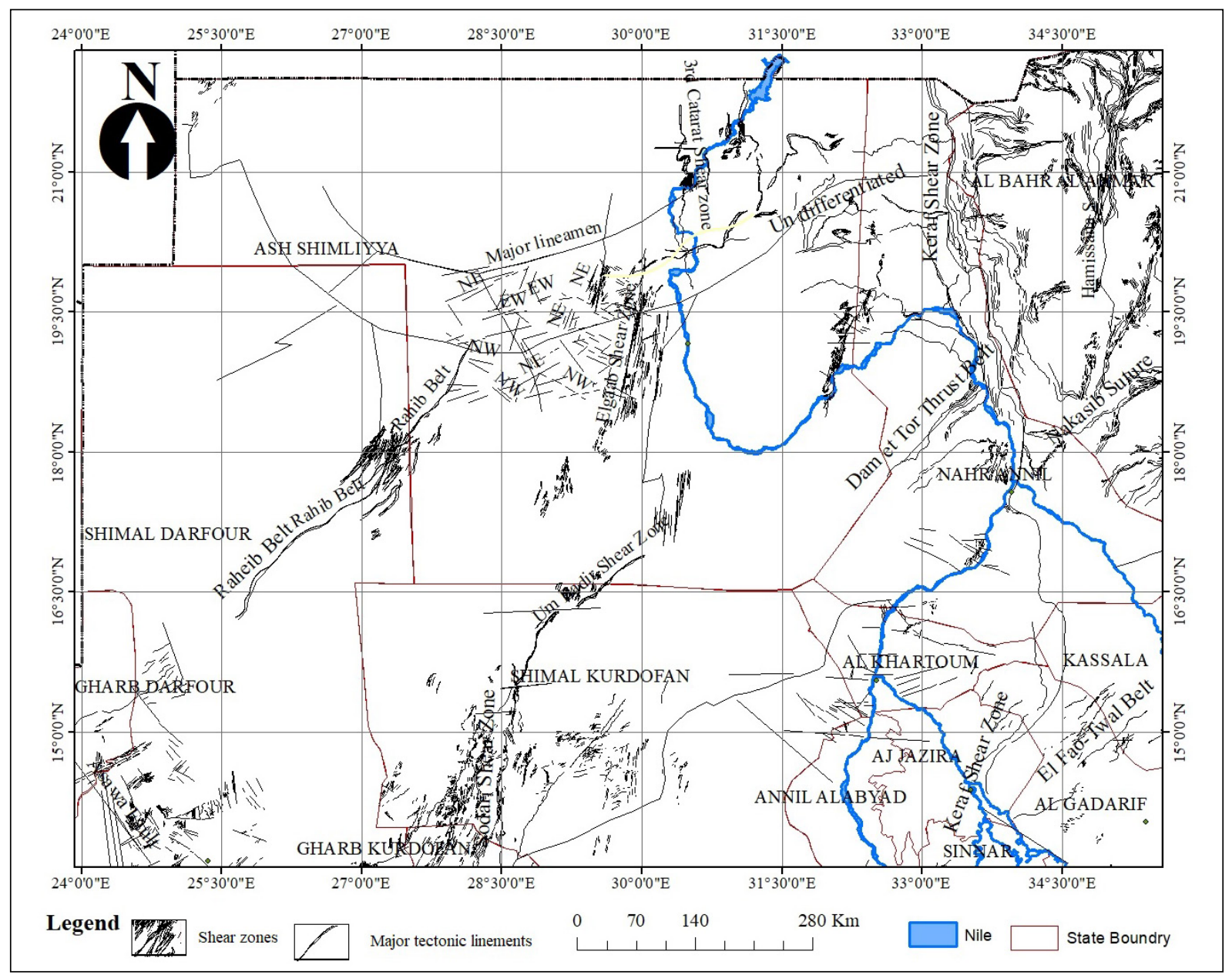

Figure 3- The tectonic map of north and central Sudan modify after tectonic and structural map of Sudan and Rose - Geo (2018) tectonic map of Sudan. 
The second phase is related with folding. Dextral shearing is the dominant one and caused the formation of $\mathrm{Z}$ - shaped chevron fold from centimeters to hundred meters in size (Figure 4c). As a result of the shearing movement quartz boundinage (pinch - and - swell) structure has formed during the third phase of deformation (Figure 4b). Similarly in Elgaab gold mineralization zone exposed subsurface structures in artisanal gold mining mega pits, shows that at least five phases of deformation have affected the area and represented by: D1; stress pressure (convergent), D2 folding, followed by D3; faults along fold axial-plane, then followed by D4; shears fabrics. D5 corresponds to tension gashes. The complex fabrics are good path ways for fertile hydrothermal fluids to precipitate gold along shear zones (Figure 4).

\section{Mineralization}

As it is known from the previous geological works in Sudan, many of the vein - type gold deposits are formed along major lineaments, such as the Oko shear zone of Nakasib suture in the Red Sea hills, Dum El Tor shear zone in Bayuda Desert and across Sodari - Umm Badr shear zones in North Kordofan (Schandelmeier and Richter, 1991; Abdel Rahman and Mahi, 2006). Vein - type gold mineralization is also formed along the $\mathrm{N}-\mathrm{S}$ trending Gabgaba lineament
(Keraf shear zone) (Vail, 1985; Kröner et al., 1987; Abdelsalam and Dawoud, 1991; Stern, 1994).

The occurrences of gold - bearing quartz veins along shear zones are controlled by tectonic lineaments with their sub - vertical tension faults (fractures). The gold - bearing quartz veins are mainly developed as fracture filling injected along the foliation planes of greenschist during Pan African Orogenic event in Late - Proterozoic era. The quartz veins were deformed by the first and second deformation phases (foliation planes). The kink band structures indicate that the veins were subjected to possible several subsequent shearing events, resulted in pinch - and - swell structure. The process and the genesis of gold mineralization may have taken place after the intrusion of granitoid particularly diorite and granodiorite, which are accepted as the source of energy that triggered the initiation of the hydrothermal activity during orogenic events. Heat source during the shearing events is responsible for re-mobilized and reconcentration of gold and associated elements across the study area, which similar processes recognized across the Arabian - Nubian Shield.

Quartz veins are usually thin and stringers are wide - spread. Many types of quartz veins are recognized and recorded; the massive smokey, grey,

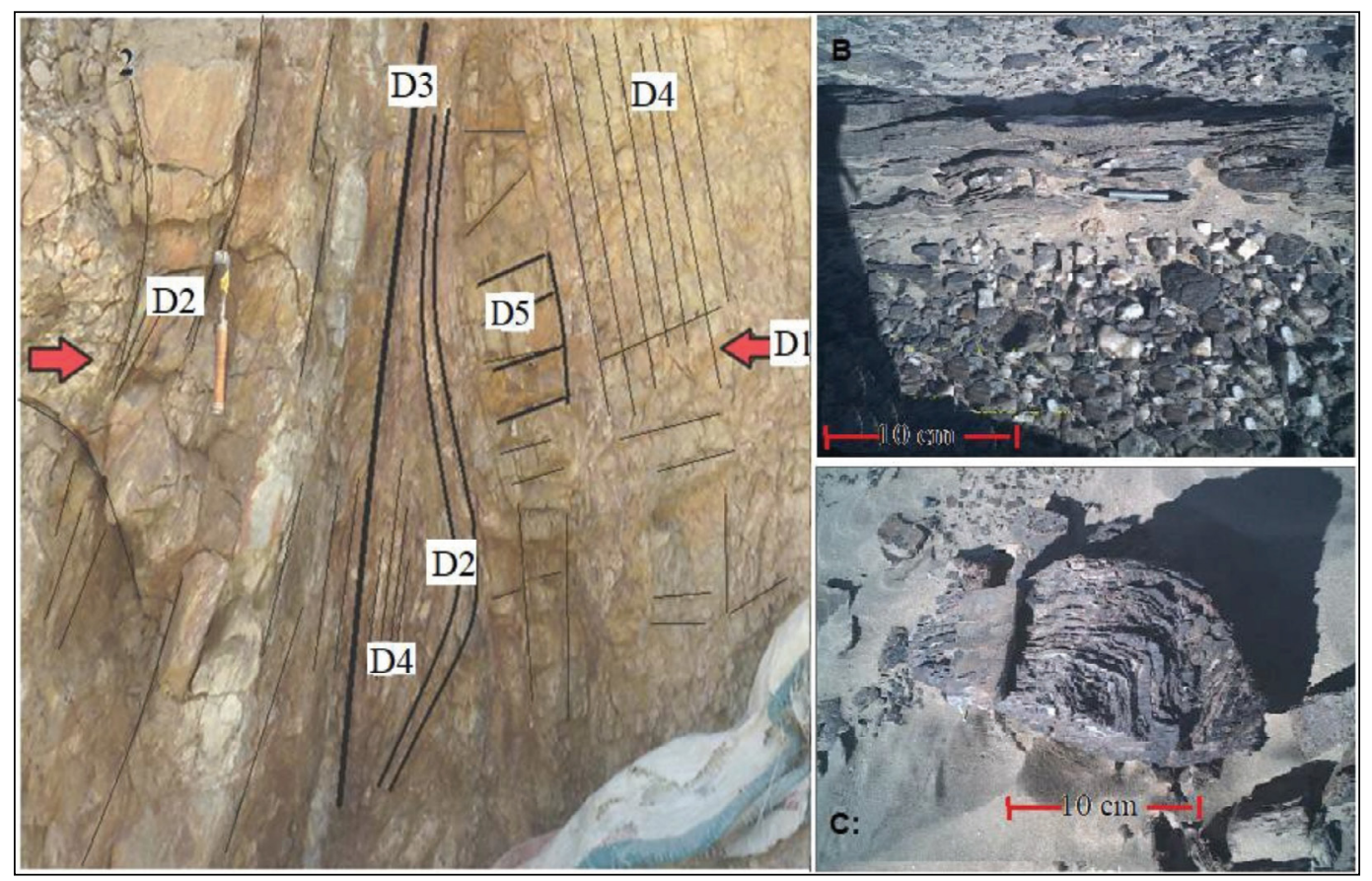

Figure 4- a) Vertical section across artisanal gold mining mega - pits illustrates the subsurface structural features, Elgaab area, b) pench and swelling - Hamadi, c) z - shape chevron fold - Hamadi. 
brecciated recrystallized, white to pinkish, and vuggy which are the richest by gold contents. The wall rock alteration is limited and confined to the area adjacent to the quartz veins, generally from $0.7 \mathrm{~m}$ to $2.00 \mathrm{~m}$ wide. Sericitization, kaolinitization, iron oxides, and iron carbonate are dominant, with rare graphite and chlorite. The gold and associated elements in Elgaab gold mineralization are arsenic, chromite and nickel, with arsenic the main pathfinders. The minerals associated to gold mineralization, based on ore microscopic investigation, are pyrite, magnetite, covellite, and chalcopyrite (Figure 5).

Hamadi gold mineralization associated with anckerite, iron oxides and tourmaline as the pathfinder (Figure 6). In Sodri - Um Badir shear zone gold mineralization in hand spacemen display dark colours, rich in sphelerite, malachite, galena, pyrite and other sulphides mineral. Nuggets of visible gold are often seen around oxidized pyrite or insides the cavities.

Gammama gold mineralization associated with copper, lead and zinc (Figure 7), with no clear pathfinder element. The mineral associated to gold mineralization based on the ore microscopy investigation, are chalcopyrite, pyrite, marcasite, hematite, and magnetite. Adularia, anckerite are indicator minerals (keys elements) and tourmaline could be a pathfinder in prospecting for gold in the study area. Electron Microscope EDS graph shows that the gold is also associated with Pd, Palladium is a precious white metal has price higher than gold (Figure 8).

\section{Geochemical Characteristics}

\subsection{Distribution of Gold and Associated Elements}

The assay results of gold and associated elements in Elgaab area $\mathrm{Cu}, \mathrm{Pb}, \mathrm{Zn}$, As beside $\mathrm{Cr}$ and $\mathrm{Ni}$, indicate that the gold content in soil samples shows higher values $(0.18-8.391 \mathrm{~g} / \mathrm{t})$ than those returned by both quartz veins ( 0.053 up to 2.93 ) and trenches samples $(0.5$ to $0.8 \mathrm{~g} / \mathrm{t})$. This disparity may be attributed to the secondary gold enrichment. Arsenic display the highest values when compared to the other trace elements. $\mathrm{Cu}, \mathrm{Pb}, \mathrm{Zn}, \mathrm{Ni}$, and $\mathrm{Cr}$ show low content and irregular distribution, except for $\mathrm{Cr}$ which
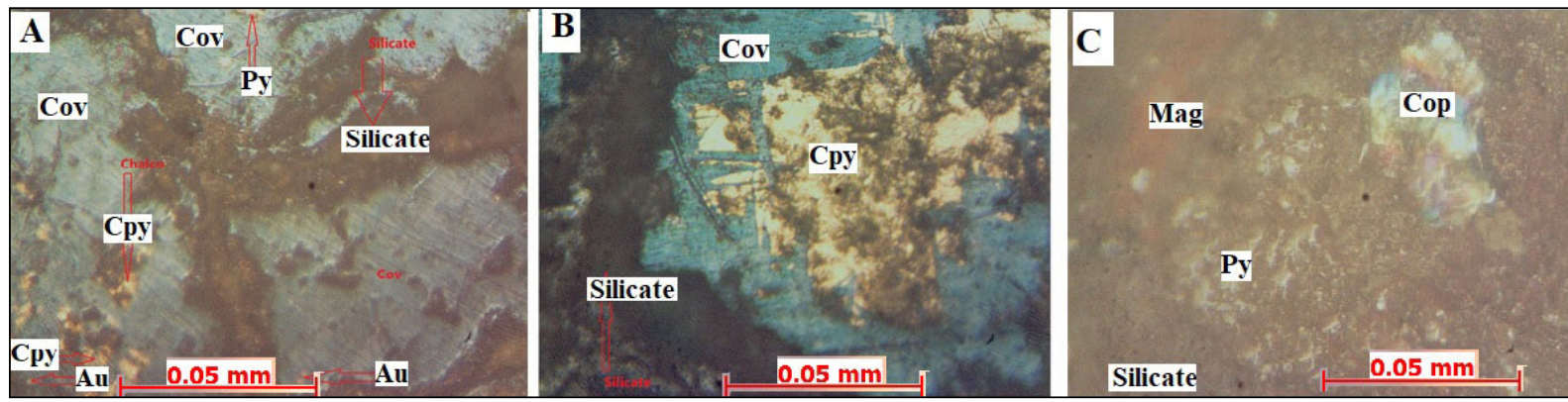

Figure 5- Light reflected microscope views of; a) pyrite (Py), primary chalcopyrite tarnished to yellow (Cpy) replaced by covellite pale blue (Cov), very find grained golden yellowish (Gol) and silicate dark grey $(20 \mathrm{X})$, b) primary chalcopyrite yellow (Cpy) replaced by covellite blue (Cov), and silicate dark grey and c) pyrite (Py), multi -colored native copper (cop), pale brown magnetite (Mag) and silicate dark grey (20X) from Elgaab area.

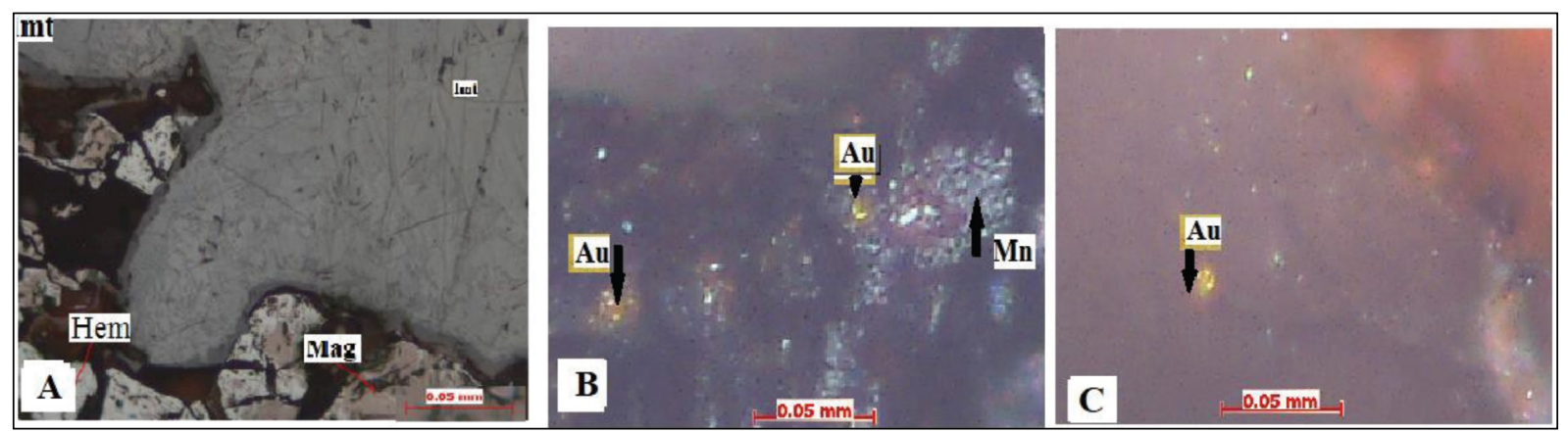

Figure 6- a),b) and c) Shows hematite, magnetite, manganese and pyrite is the most common minerals associated with gold in (Hamadi) Dom el Tor shear zone. 

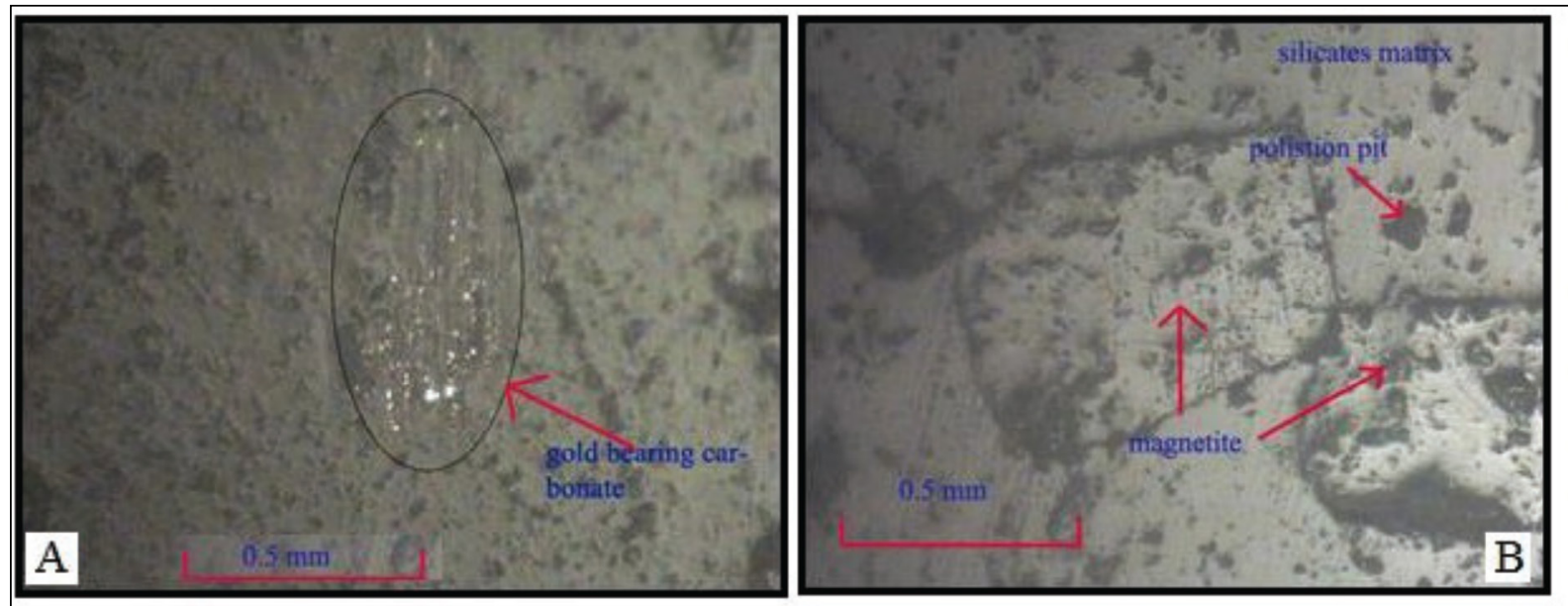

Figure 7- a) Shows gold bearing carbonate, Gammama (Sodari shear zone), b) photomicrograph shows cubic magnetite, Gammama.

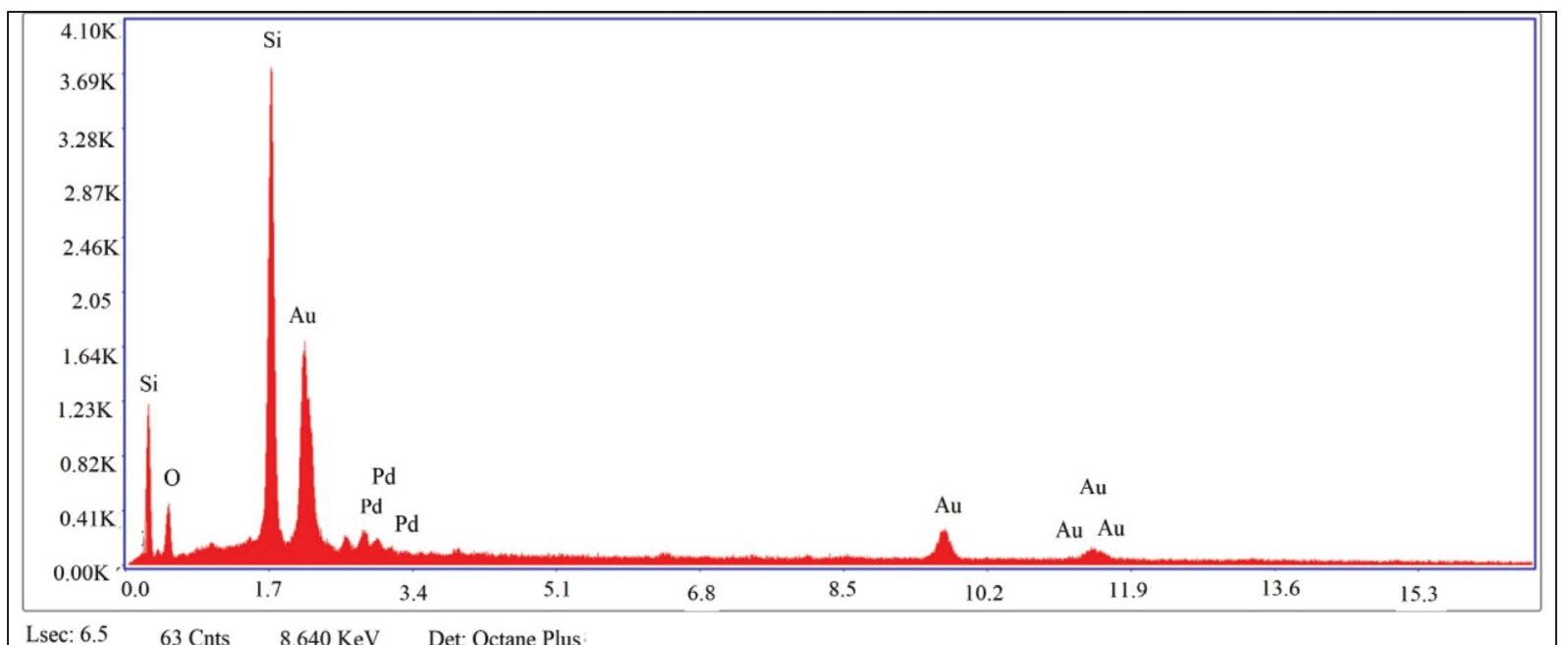

Figure 8- Electron scan microscope graph shows the gold associated with Pd.

has a medium concentration. Arsenic shows irregular but very high content that range between $197-17905$ ppm. Zn; content range between (16 to $880 \mathrm{ppm}$ ). Trace elements Th, Ba, Co, Ga, Mo, Ge, W, V, Nb, $\mathrm{Zr}, \mathrm{Y}, \mathrm{Sc}, \mathrm{Rb}-\mathrm{Sr}, \mathrm{Hf}$, analysis results obtained from quartz veins samples reveal very low values. Except $\mathrm{Ni}, \mathrm{Cr}, \mathrm{Pb}, \mathrm{Zn}$ and $\mathrm{Cu}$ shows relatively medium to high values. Cerium $(\mathrm{Ce})$, shows very low value among all samples. $\mathrm{Pb}$ content range between (19 to $253 \mathrm{ppm}$ ) and (40 to $180 \mathrm{ppm}$ ) for quartz veins and soil samples from Elgaab mineralization zone, respectively single elements geochemical mapping "iso - concentrate map" is usually used as an effective tool for assign the areas of anomalous value as well as the trend of mineralization.
It is worth mentioning that, prospecting criteria or evidences for $\mathrm{Cu}, \mathrm{Pb}$ and $\mathrm{Zn}$, gossans - like and VMS mineralization in Elgaab and Hamadi areas are not recognized during this study. Meanwhile those criteria are recorded in North Kurdofan along Sodri Umm Badir shear zones. The chemical analysis reveal high $\mathrm{Au}$ values ranging between 0.49 and $10.00 \mathrm{~g} / \mathrm{t}$, while Ag shows relatively medium values ranging between 3 and $5 \mathrm{ppm}$. $\mathrm{Zn}$ and $\mathrm{Pb}$ lead display low concentrations ranging between 8 and $129 \mathrm{ppm}$ and 5 and $79 \mathrm{ppm}$, respectively. In contrast $\mathrm{Cu}$ shows the highest concentration values ranging between $14500-77200 \mathrm{ppm}$. Assay results of quartz veins samples, from Hamadi gold mine, Dom el Tor shear zone, reveal Au content vary between ( 0.11 to 10.25 $\mathrm{g} / \mathrm{t})$. The relative high coefficient of variation of $\mathrm{Au}$ 
$(156.75 \%-252.6307 \%)$ suggests that $\mathrm{Au}$ is inhomogeneously, or irregular distributed in quartz veins when compare to $\mathrm{Au}$ content in soil. $\mathrm{Cu}$ has highly potential content (14500 - 772000 ppm), which is considered to be highly anomalous in Gammama Sodri - um Badir shear zone the presence of sulphides, such as pyrite $\left(\mathrm{FeS}_{2}\right)$ chalcopyrite $\left(\mathrm{CuFeS}_{2}\right)$, and galena $(\mathrm{PbS})$, could indicate shear-related massive sulphides mineralization at depth.

The histograms for $\mathrm{Au}$, and associated $\mathrm{Cu}, \mathrm{Pb}$, $\mathrm{Zn}, \mathrm{Ni}$ and $\mathrm{Cr}$ for the rocks and quartz veins samples in Elgaab area of study are displaying irregular distributions for the elements described. The histogram of frequencies shows the whole population in the curve of frequencies is bimodal. That means the whole population is split into $2 \mathrm{sub}$ - populations background and anomalous (Figure 9). The high coefficient of variation indicate irregular erratic distribution of gold in quartz veins. While in Hamadi gold mine area the histogram of $\mathrm{Au}$ display same population, the $\mathrm{Au}$ content range between $0.49-10.00$ ppm (Figure 10).

In Sodri - Um Badir shear zone gold mineralization histogram for $\mathrm{Au}, \mathrm{Ag}, \mathrm{Zn}, \mathrm{Pb}$ and $\mathrm{Cu}$ displays irregular symmetrical distribution of $\mathrm{Au}, \mathrm{Zn}, \mathrm{Pb}$ and $\mathrm{Cu}$ while $\mathrm{Ag}$ shows regular symmetrical distributions (Figure 11).

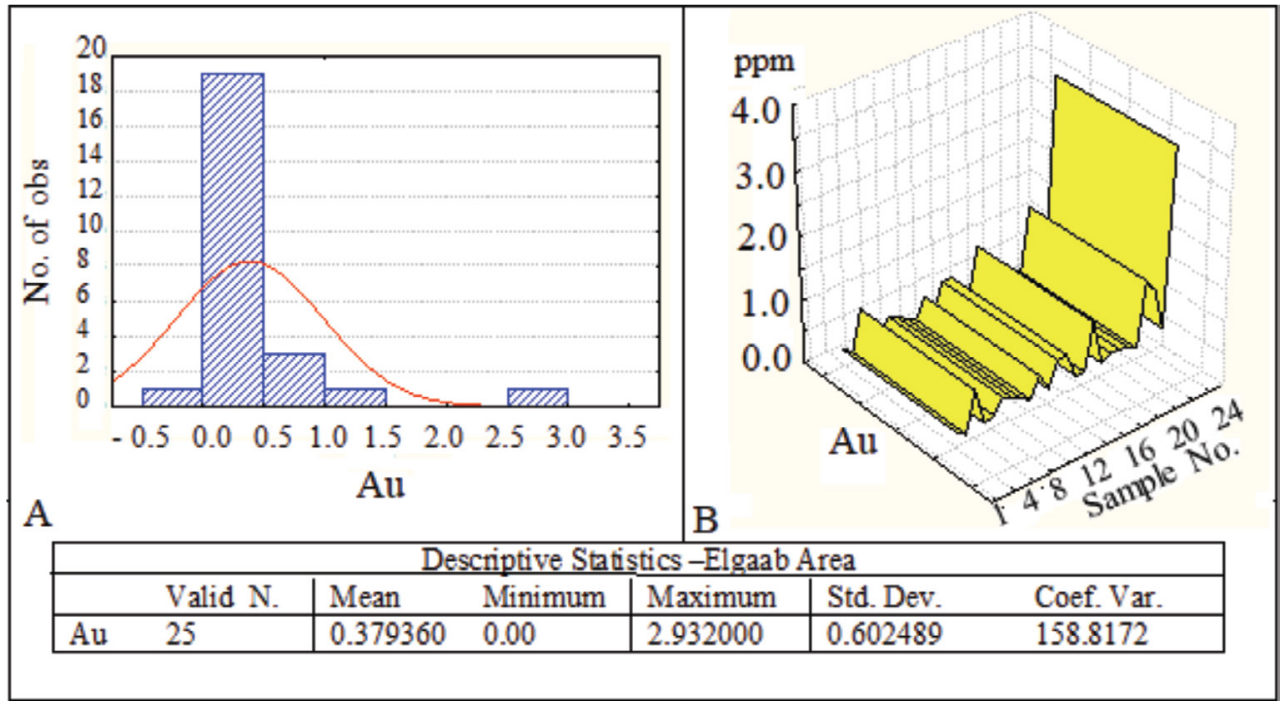

Figure 9- Hamadi area; a) histogram of $\mathrm{Au}$ and b) sequential graph.

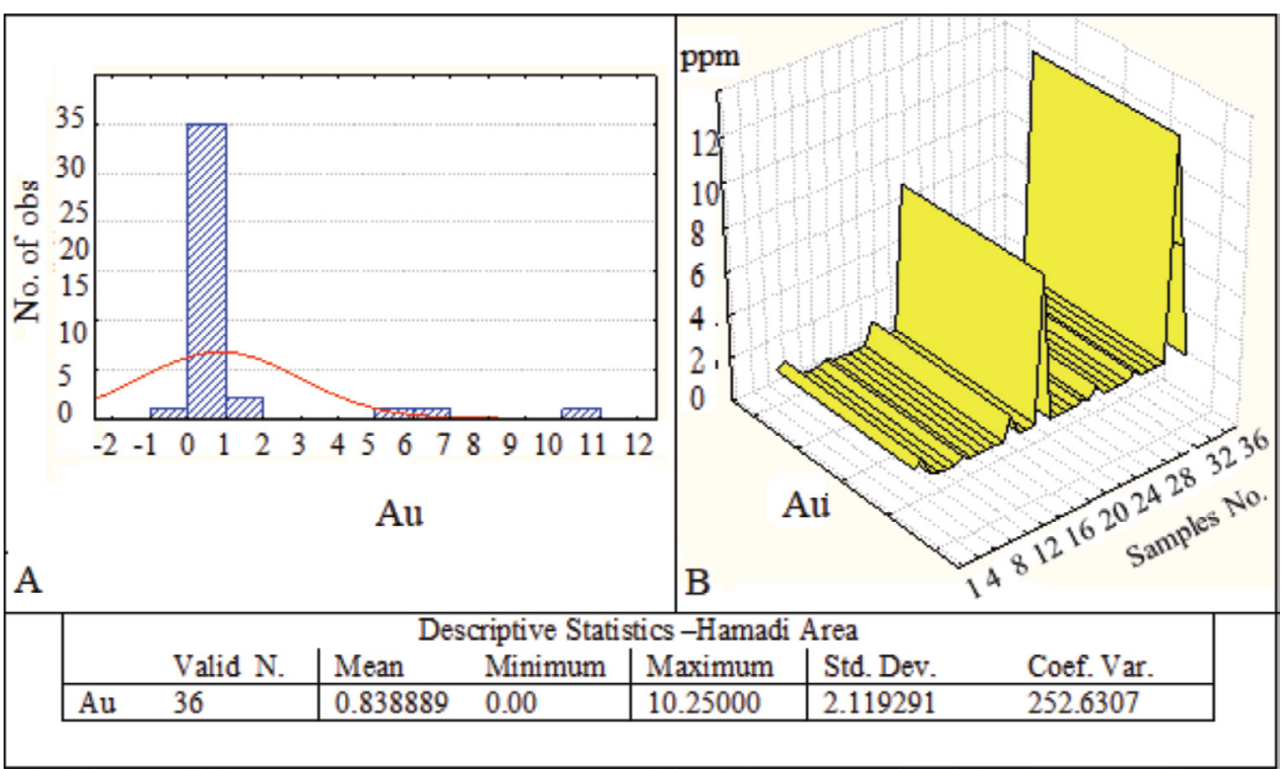

Figure 10- Hamadi area; a) histogram of $A u$ and b) sequential graph. 


\subsection{Correlation}

The proportion of quartz veins samples from Elgaab study area containing gold above the detection limit is $77.4 \%$. Were the detection limit is $0.001 \mathrm{ppm}$, with mean value $4.416 \mathrm{ppm}$. The correlation matrix indicate that $\mathrm{Cu}$ versus $\mathrm{Au}$ show no correlation. $\mathrm{Au}$ versus $\mathrm{Pb}(0.05)$ and $\mathrm{Zn}(0.07)$ show very weak positive correlation. Au versus $\mathrm{Cr}(-0.02)$ show negative weak correlation. Au versus $\mathrm{Ni}(-0.10)$ show negative correlation. While Au versus As (0.90) shows very strong positive correlation, the correlation matrix display that $\mathrm{Au}$ versus $\mathrm{Cu}(0.45)$ has perfect correlation. The source of the high $\mathrm{Cu}$ content are possibly due to the associating chalcopyrite and malachite observed in auriferous quartz vein in the vicinity of the mineralization zone. $\mathrm{Au}$ versus $\mathrm{Pb}$ $(-0.06)$ shows negative weak correlation, and $\mathrm{Zn}$ (0.49) shows positive perfect correlation, while $\mathrm{Pb}$ versus $\mathrm{Cr}$ and $\mathrm{Ni}$ show positive correlation. $\mathrm{Pb}$ versus As show weak positive correlation (Table 1).
The chemical analysis results reveals low values for $\mathrm{Pb}$ in both Elgaab and Sodri - Um Badir areas of study. $\mathrm{Zn}$ versus $\mathrm{Au}$ shows weak positive correlation. On other hand $\mathrm{Zn}$ shows no correlation with both $\mathrm{Cu}$ and $\mathrm{Pb}$. $\mathrm{Zn}$ versus Ni shows weak positive correlation, and versus both $\mathrm{Cr}$ and As shows weak negative correlation. The chemical analysis results reveals low values for $\mathrm{Zn}$ in Sodri - Um Badir as compared to values obtained for Elgaab area of study. $\mathrm{Zn}$ and $\mathrm{Pb}$ were detected in hand specimens by their minerals ore sphelerite and galena, respectively. Although the chemical analysis results reveals low values, in Gammama site of Sodri - Um Badir shear zones (Table 2).

Numerous minerals deposit of economic potential have found to be occurring along shear zone and associated gashes and faults. This could be realized by detail exploration using advanced geophysics techniques and deep drilling. In this respect, the study

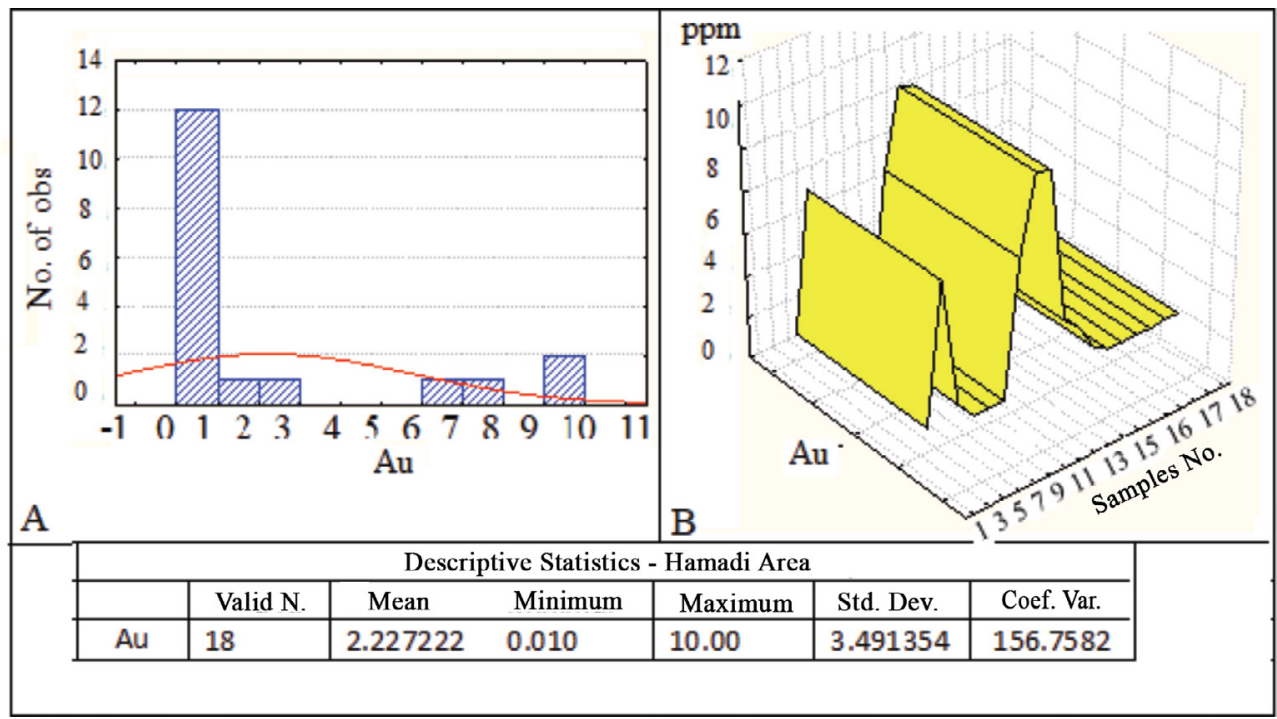

Figure 11- Gammama area; a) histogram of Au and b) sequential graph.

Table 1- Correlations matrix (Elgaab) gold and associated elements.

\begin{tabular}{|l|c|c|c|c|c|c|c|}
\hline & $\mathbf{A u}$ & $\mathbf{C u}$ & $\mathbf{P b}$ & $\mathbf{Z n}$ & $\mathbf{N i}$ & $\mathbf{C r}$ & $\mathbf{A s}$ \\
\hline $\mathbf{A u}$ & 1.00 & & & & & & \\
\hline $\mathbf{C u}$ & -0.00 & 1.00 & & & & & \\
\hline $\mathbf{P b}$ & 0.05 & -0.01 & 1.00 & & & & \\
\hline $\mathbf{Z n}$ & 0.07 & 0.05 & -0.08 & 1.00 & & & \\
\hline $\mathbf{N i}$ & -0.10 & 0.74 & 0.43 & 0.14 & 1.00 & & \\
\hline $\mathbf{C r}$ & -0.02 & 0.05 & 0.58 & -0.21 & 0.36 & 1.00 & \\
\hline $\mathbf{A s}$ & 0.90 & 0.05 & 0.11 & -0.08 & -0.01 & -0.04 & 1.00 \\
\hline
\end{tabular}

Table 2-Correlations matrix (Gammama) gold and associated elements.

\begin{tabular}{|c|c|c|c|c|c|}
\hline & $\mathbf{A u}$ & $\mathbf{A g}$ & $\mathbf{Z n}$ & $\mathbf{P b}$ & $\mathbf{C u}$ \\
\hline $\mathbf{A u}$ & 1.00 & & & & \\
\hline $\mathbf{A g}$ & -0.118319 & 1.00 & & & \\
\hline $\mathbf{Z n}$ & 0.49 & 0.35 & 1.00 & & \\
\hline $\mathbf{P b}$ & -0.06 & 0.15 & 0.54 & 1.00 & \\
\hline $\mathbf{C u}$ & 0.45 & 0.03 & 0.326 & 0.33 & 1.00 \\
\hline
\end{tabular}


points to five selected targets for future gold follow up exploration (Figure 12).

\section{Results}

The areas of study intersected by three major shear zones namely; Elgaab, Gammama in Sodri - Um Badir and Hamadi mine of Dom el Tor shear zone. All zones constitute huge flat area of sandy sheets covering both Phanerozoic sediments and underlying basement rocks. Volcano - sedimentary sequences of NeoProterozoic and partially Meso - Proterozoic granitic gneiss were intruded by syn to late granitoid intrusions, and later by post orogenic granite and felsic dykes. The gold - bearing quartz veins are mainly developed as fracture filling injected along the foliation planes of green-schist rocks, formed at different stages during the Pan - Africa Orogenic events (900 - 550 Ma.).
The geological, lithological, structural criteria and geochemical mapping indicate that the mineralization domains are confined to the NNE shear and related tensional gashes. Thus, Elgaab gold mineralization could be classified as epigenetic shear - related mineralization. The process and the genesis of gold mineralization emplacement may had taken place after the intrusion of batholithic granitoids particularly diorite and granodiorite, which were believed to be the source of energy that triggered the hydrothermal solutions during orogenic events. While the heat generated during the shearing events could be responsible for re-mobilization and re-concentration (enrichment) of gold and associated elements across the area of study, in similar process as documented in Arabian - Nubian Shield.

The assay results of $\mathrm{Au}$ and the associated $\mathrm{Cu}$, $\mathrm{Pb}, \mathrm{Zn}, \mathrm{As}, \mathrm{Cr}$ and $\mathrm{Ni}$ in Elgaab area indicate that the



Figure 12- Location map of the selected five prospective areas for future gold exploration. 
$\mathrm{Au}$ content in the soil samples are of higher values content $(0.18-8.391 \mathrm{~g} / \mathrm{t})$ than those revealed by both primary lodes $(0.053$ up to $2.93 \mathrm{~g} / \mathrm{t})$ and trenches samples $(0.5$ to $0.8 \mathrm{~g} / \mathrm{t})$ respectively. The relative high coefficient of variation of $\mathrm{Au}(158.8 \%)$ suggests that $\mathrm{Au}$ is inhomogeneously and irregularly distributed in quartz veins. Assay results of samples from Hamadi gold mine quartz veins reveal that Au content varies between 0.11 and $10.25 \mathrm{~g} / \mathrm{t}$. The mineral associated with gold mineralization are chalcopyrite, pyrite, marcasite, hematite, and magnetite. Adularia and ankerite are indicator minerals (keys elements), whereas tourmaline could be a pathfinder. Electron Microscope - Electron dispersion spectrometry (EDS) shows that the $\mathrm{Au}$ is also associated with $\mathrm{Cu}$ and $\mathrm{Pd}$. The results of analysis of quartz veins samples from Gammama in Sodri - Um Badir shear related - gold mineralization indicate that the elements associated with $\mathrm{Au}$, are $\mathrm{Ag}, \mathrm{Zn}, \mathrm{Pb}$ and $\mathrm{Cu}$. The $\mathrm{Au}$ content ranges between 0.49 and $10.00 \mathrm{ppm}$, while $\mathrm{Cu}$ has anomalous values as higher as $77200 \mathrm{ppm}$. The presence of sulphides, such as pyrite $\left(\mathrm{FeS}_{2}\right)$ chalcopyrite $\left(\mathrm{CuFeS}_{2}\right)$, and galena (PbS), along Sodri - Umm Badir shear zones in North Kurdofan suggests the presence of shear - related massive sulphides mineralization at depth.

Comparison between Elgaab shear zone gold mineralization, Dum el Tor shear - related gold mineralization and Sodri - Um Bader shear mineralization indicates similarities in lithological characteristics of Upper Proterozoic rock assemblages. The NNE - SSW and NE - SW structural grain of Pan African Arabian- Nubian Shield were dominant, as well as the mode of occurrences of the ore bodies, and the grade of metamorphism. Regardless of those similarities there are broad variations in the metallogenic characteristics such as mineral association, pathfinder, and grade of gold content.

The results of this study define new metallogenic province in the region west of the River Nile. West of Dongla the province constitutes a huge sandy area lying between Elgaab, Dam el Tor and Sodri - Umm Badir shear zones cover the Phanerozoic sediments and basement assemblages. Nemours minerals deposit of economic potential have found to be occurring along shear zones and associated gashes and faults. This could be further realized by detailed exploration using advanced techniques and deep drilling. In this respect, the study pointed out five potential targets for future gold exploration and evaluation, according to litho - stratigraphic similarity, geochemical and geotectonic characteristics.

\section{Acknowledgment}

This study was completed as a part of thesis submitted for the degree of Doctor of Philosophy $(\mathrm{PhD})$ in Geological Sciences faculty of petroleum and minerals, Alnileen University, Khartoum. I would like to thanks to Professor Badr el Din Khalil and Dr. Mohammed Yahia for their contributions to develop this article.

\section{References}

Abdel Rahman, E. M., El Mahi J. E. 2006. A new discovery of base metals - precious metals mineralization in North Kordofan, Sudan: implications for trans - shield mineralized corridors. The 9th Arab Conference for Minerals Resources, Jeddah, Saudi Arabia, 33.

Abdelsalam, M. G., Dawoud, A. S. 1991. The Kabus ophiolite mélange, Sudan, and its bearing in the western boundary of the Nubian Shield. Journal of the Geological Society, London 148, 83-92.

Abdelsalam, M. G., Stern, R. J., Schandelmeier, H., Sudan, M. 1995. Deformational history of the Keraf Zone in NE Sudan. Journal of Geology 103, 475-491.

Harms, U., Darbyshire, D. P. F., Denkler. T., Hengest, M., Schandelmeier, H. 1994. Evolution of the new Proterozoic Delgo suture zone and crustal growth in Northern Sudan: geochemical and radiometric isotope constrain. Geologische Rundschau 83, 591-603.

Kröner, A., Greling, R., Reischmann, T., Husein, I. M., Stern, R. J., Durr, S., Kruger, J., Zimmer, M. 1987. Pan African crustal evaluation in the Nubian segment of the North East Africa. American Geophysical Union Series 17, 235-257.

Kuster, D., Liegeois, J. P. 2001. Sr, Nd isotopes and geochemistry of the Bayuda Deserthigh - grade metamorphic basement (Sudan): an early Pan African oceanic convergent margin, not the edge of the East Saharan ghost craton. Precambrian Research 109(1-2), 1-23.

Schandelmeier, H., Richter, A. 1991. Brittle shear deformation in Northern Kordofan, Sudan: Late Carboniferous to Triassic reactivation of Precambrian fault systems. Journal of Structural Geology 13(6), 711-720. 
Bull. Min. Res. Exp. (2021) 165: 1-12

Stern, R. G., Reischman, T., Bender, R., Dawoud, A. S. 1994. Precambrian basement around Wadi Halfa; a new prospective of evolution of east Sahara Carton. Geologische Rundschau 83, 564-575.

Rose Geo. 2018. A report submitted to GRAS within the frame work of technical cooperation agreement. GRAS, Report No: 1 (2), Moscow (unpublished).
Vail, J. R. 1985. Pan African (Late Precambrian) tectonic terrains and reconstruction of the Arabian Nubian Shield. Geology 13, 839-842. 